\title{
PENGEMBANGAN MODUL SETS PADA MATERI CAHAYADAN ALAT OPTIK KELAS VIII SMP/MTS
}

\author{
Wahyu Kodrat Listianthy ${ }^{1}$ Sarwanto $^{2}$ dan Meti Indrowati $^{3}$ \\ 1,2,3 Program Studi Sarjana Pendidikan IPA FKIP Universitas Sebelas Maret
} Surakarta, 57216, Indonesia

Email: ${ }^{1}$ wahyukl@student.uns.ac.id; ${ }^{2}$ sarwanto@fkip.uns.ac.id; ${ }^{3}$ metiindrowati@staff.uns.ac.id

Diajukan: 15 Agustus 2021; Diterima: 2 September 2021; Diterbitkan: 30 Oktober 2021

\begin{abstract}
Abstrak: Penelitian pengembangan kali ini untuk melihat kelayakan modul SETS (Science, Environment, Technology, and Society) pada sifat cahaya dan optik untuk kelas VIII di SMP dan respon siswa. Penelitian ini menggunakan desain Research and Development (R\&D) yang mengadaptasi desain penelitian pengembangan model 4-D dari Thiagarajan, et al. yang meliputi 4 tahap: define, design, develop, dan disebarluaskan. Namun, penelitian ini hanya dilakukan sampai tahap develop (3-D). Penelitian pengembangan ini diawali dengan observasi lapangan dan studi pustaka, kemudian dikembangkan dengan desain awal modul. Rancangan awal modul kemudian divalidasi oleh ahli materi, ahli media, pengembangan pendidikan dan peer review. Selanjutnya dilakukan uji coba terbatas dengan melibatkan 10 siswa sebagai subjek penelitian. Teknik data dilakukan melalui observasi, wawancara, dokumentasi, dan angket. Teknik analisis menggunakan analisis kuantitatif perolehan nilai validasi kelayakan modul dan analisis deskriptif. Hasil penelitian menunjukkan bahwa modul SETS (Ilmu Pengetahuan, Lingkungan, Teknologi, dan Masyarakat) sifat cahaya dan optik untuk kelas VIII di sekolah menengah pertama diukur dengan kriteria sangat valid berdasarkan hasil validasi, dari validasi tersebut kami menyimpulkan bahwa modul tersebut layak untuk digunakan. gunakan dalam pembelajaran sains.
\end{abstract}

Kata kunci: Modul, pendekatan SETS, kelayakan, sifat cahaya dan optik

Abstract: The development research is aimed to see the feasibility of SETS (Science, Environment, Technology, and Society) modules on light and optical properties for grade VIII in junior high school and the response of students. This study uses a Research and Development $(R \& D)$ design which adapts the 4-D model development research design from Thiagarajan, et al. which includes 4 stages: define, design, develop, and disseminate. However, the research is only done up to the develop stage (3-D). This development research begins with field observations and literature study, then developed with the initial design of the module. The initial design of the module is then validated by material experts, media experts, developing education and peer reviews. Furthermore, a limited trial was carried out involving 10 students as research subjects. The data technique was carried out through observation, interviews, documentation, and questionnaires. The analysis technique uses quantitative analysis of the acquisition of module feasibility validation scores and descriptive analysis. The results showed that the SETS (Science, Environment, Technology, and Society) module light and optical properties for grade VIII in junior high school were measured as very valid criteria based on validation results, from the validation we conclude that the module is suitable for use in science learning.

Keywords: Modules, SETS approach, feasibility, light and optical properties

\section{Pendahuluan}

Pembelajaran IPA merupakan sebuah pembelajaran yang menekankan pada konsep pembelajaran mengenai fenomenafenomena nyata alam sekitar agar peserta didik dapat mengembangkan kompetensi dan mendapatkan pengalaman secara langsung (Safitri et al, 2018: 22). IPA memiliki tujuan dalam mengembangkan ilmu pengetahuan dan teknologi (IPTEK), membantu manusia dalam menyelesaikan masalah dalam kehidupan sehari-hari, serta mendorong manusia untuk menjaga kelestarian lingkungan (Wijaya \& Fajar, 2020: 9). Keberhasilan dari tujuan tersebut menjadi tanggung jawab semua pihak, baik pemerintah sebagai pembuat kebijakan, pihak sekolah sebagai penyelenggara pendidikan, serta masyarakat yang mendukung sumber daya yang dibutuhkan oleh sekolah (Asmuri et al, 2018: 73). Sehingga tujuan pembelajaran IPA menjadi dasar untuk 
menghasilkan sumber daya manusia yang memiliki mutu dan kualitas tinggi (Hayati et al, 2019: 249).

Hasil survei yang dilakukan oleh PISA (Program for International Student Assessment) pada tahun 2018, Indonesia berada di peringkat sepuluh terbawah untuk kategori sains. Pada kategori sains Indonesia meraih rata-rata skor 396 dan menduduki peringkat 63 dari 71 negara yang disurvei (OECD, 2018). Hasil survei tersebut mengandung makna bahwa kualitas pendidikan di negara Indonesia, khususnya dalam bidang sains memerlukan perhatian khusus dan pengkajian lebih lanjut untuk menemukan solusi agar kualitas pendidikan di Indonesia semakin berkembang.

Hakikat dari IPA merupakan sebuah proses penemuan konsep dari suatu fenomena yang dilakukan secara sistematis. Kaitannya dengan hal tersebut, Rahim (2019: 26) mengatakan bahwa dengan mempelajari sains, peserta didik dapat memahami diri dan lingkungan tempat tinggalnya serta aplikasi dari sains itu sendiri dalam kehidupan. Pendapat tersebut mengandung makna bahwa pembelajaran IPA sebagai ilmu pengetahuan sangat erat kaitannya dengan lingkungan sekitar termasuk kehidupan bermasyarakat serta kaitannya dengan penerapan keilmuan tersebut menjadi teknologi.

Fakta di lapangan menunjukkan bahwa masih belum ada kolaborasi antara unsur-unsur yang saling berkaitan tersebut. Keadaan tersebut sejalan dengan pendapat Sari et al. (2016) yang mengungkapkan jika bahan ajar di lapangan masih banyak membahas tentang konsep yang bersifat teoritis yang berisi rangkuman materi dan latihan soal-soal, masih jarang membahas tentang peran sains dalam kehidupan sehari-hari. Hakikat keilmuan IPA mencakup empat unsur penting, yaitu proses, produk, sikap serta aplikasi dari keilmuan itu sendiri dalam kehidupan. Kenyataannya pembelajaran masih terfokus pada IPA sebagai produk yang meliputi fakta, konsep, prinsip maupun hukum. Pembelajaran belum menghubungankan dengan permasalahan lingkungan, teknologi serta masyarakat. Hal tersebut menjadi penyebab pembelajaran kurang bermakna dan membuat kelas menjadi pasif (Sari, et al., 2016). Keadaan tersebut menunjukkan jika pemahaman IPA sebagai proses, sikap, serta aplikasi dalam kehidupan sehari-hari belum dikembangkan secara maksimal. Sehubungan dengan hal tersebut, guru perlu memilih pendekatan serta metode pembelajaran yang bukan hanya bertumpu pada penguasaan materi namun juga mengacu pada proses yang terjadi di dalamnya.

Selain pendekatan serta metode pembelajaran yang tepat, komponen lain yang juga mendukung keberhasilan pembelajaran adalah bahan ajar. Bahan ajar yaitu sekumpulan materi pembelajaran yang disusun dengan rinci sehingga dapat dipahami dan dapat memenuhi kebutuhan belajar peserta didik (Rochmawati et al., 2017). Hasil wawancara kepada guru IPA SMP Negeri 1 Banyudono menunjukkan bahwa bahan ajar yang menjadi acuan yaitu BSE (Buku Sekolah Elektronik) dari Kementerian Pendidikan dan Kebudayaan, Lembar Kerja Peserta Didik, serta buku pendamping dari penerbit. Desain dari bahan ajar tersebut umumnya masih belum mencerminkan pemahaman IPA sebagai proses, produk, sikap, serta aplikasi. Setiap bahan ajar belum sepenuhnya menunjukkan keterkaitan antara ilmu pengetahuan (sains) dengan lingkungannya serta masyarakat dan juga penerapannya dalam kehidupan.

Hasil observasi lapangan di SMP Negeri 1 Banyudono saat pelaksanaan magang kependidikan menunjukkan jika isi dari masing-masing bahan ajar belum mencakup seluruh komponen IPA. Misalnya BSE dari Kemendikbud yang dirancang untuk membantu peserta didik berpikir aktif menemukan suatu konsep melalui berbagai kegiatan eksperimen yang tersedia. Akan tetapi, materi yang tersedia di dalamnya tidak dibahas secara mendalam. Sehingga peserta didik sulit untuk menggunakan BSE untuk dipelajari secara mandiri. Sedangkan buku pendamping lebih menekankan pada teori serta konsep dan tidak banyak menyinggung IPA dalam kehidupan sehari-hari. LKPD hanya memberikan petunjuk bagi peserta didik untuk melakukan sebuah problem solving (pemecahan masalah) yang dilakukan melalui sebuah praktikum.

Upaya yang dapat dilakukan untuk mengatasi hal tersebut yaitu membuat sebuah inovasi baru untuk bahan ajar bagi peserta 
didik. Salah satu upaya tersebut yaitu mengembangkan sebuah bahan ajar yang dapat digunakan peserta didik dalam belajar mandiri. Bahan ajar yang dimaksud berupa modul. Modul sendiri merupakan bahan ajar yang didesain dan dicetak agar dapat dipelajari oleh peserta didik secara mandiri (Rochmawati, et al., 2017). Seperti yang diungkapkan oleh Wijayanti et al. (Rochmawati, et al., 2017) jika penyajian materi dalam modul dianggap lebih efektif dan menarik, karena membantu meningkatkan motivasi belajar serta membantu peserta didik menguasai konsep lebih cepat.

Desain modul yang dikembangkan harus sesuai dengan hakikat keilmuan IPA yaitu berkaitan dengan lingkungan sekitar dan aplikasi dalam kehidupan masyarakat. Salah satu pendekatan pembelajaran yang sesuai yaitu pendekatan SETS (Science, Environment, Technology, dan Society) atau bisa disebut dengan pendekatan salingtemas (sains, lingkungan, teknologi, dan masyarakat). Pendekatan SETS adalah pendekatan yang beorientasi pada peserta didik dimana pendekatan ini menghubungkan antara pembelajaran dengan peristiwa yang terjadi di lingkungan sekitar (Pedretti \& Nazir, 2011). Pendekatan SETS mengandung empat konsep seperti yang dijelaskan oleh Bencze et al. (2019: 5) dalam studinya yang menyatakan bahwa pendekatan SETS merupakan sebuah pendekatan pembelajaran yang terfokus pada empat unsur penting, yaitu sains, lingkungan, perkembangan teknologi, dan kehidupan bermasyarakat yang menempatkan pengetahuan dalam konteks sosial, teknologi, budaya, dan politik.

Pendekatan SETS merupakan pendekatan pembelajaran yang cocok untuk diterapkan agar para pembelajar tidak hanya menguasai konsep materi, namun juga berorientasi kepada proses dan aplikasi dalam kehidupan bermasyarakat. Pendapat tersebut sejalan dengan Harahap et al. (2017: 96) yang mengungkapkan bahwa pendekatan SETS dapat meningkatkan pemahaman serta penerapan ilmu pengetahuan yang telah didapat peserta didik guna menghadapi permasalahan yang ditemukan sehari-hari.

Sebuah pendekatan akan berhasil diterapkan dalam pembelajaran apabila disampaikan dengan metode yang cocok.
Beberapa metode pembelajaran dapat diterapkan dalam pendekatan SETS, salah satunya yaitu metode eksperimen. Chowdhury (2016) berpendapat jika pendekatan SETS dapat menciptakan suasana belajar yang menyenangkan di dalam kelas serta membentuk interaksi sosial, sehingga guru mengembangkan metode pada pendekatan SETS dengan metode eksperimen melalui kegiatan praktikum. Hal ini sesuai dengan pendapat Yuliati (2015) yang mengatakan jika salah satu metode pembelajaran IPA yang mampu merangsang keterampilan proses dari peserta didik antara lain, metode eksperimen, demonstrasi, dan juga diskusi.

$$
\text { Metode eksperimen dapat }
$$

memberikan pengalaman secara langsung kepada peserta didik dalam hal penemuan konsep pembelajaran. Metode eksperimen merupakan metode pembelajaran yang melibatkan peserta didik secara langsung dalam pembelajaran sehingga peserta didik mendapatkan pengalaman belajar secara langsung dengan membuktikan sendiri melalui proses ilmiah. Hasil penelitian yang dilakukan oleh Sari, et al. (2016) yang menyatakan bahwa modul pembelajaran IPA berbasis Salingtemas di SMP yang dikembangkan dinyatakan valid. Hasil belajar peserta didik setelah menggunakan modul tersebut pun tergolong tinggi. Beberapa masalah yang ditemukan di lapangan dan penelitian tentang pendekatan SETS ini yang mendasari dilakukannya pengembangan modul SETS pada materi cahaya dan alat optik.

\section{Metode Penelitian}

Penelitian ini menggunakan desain penelitian pengembangan model 4-D dari Thiagarajan, et al. Tahap penelitian tersebut meliputi empat tahapan, yaitu define (pendefinisian), design (perancangan), develop (pengembangan), dan disseminate (penyebaran). Namun penelitian hanya dilakukan sampai uji coba terbatas pada tahap develop (3-D) saja. Tahap uji coba utama dan tahap disseminate (penyebaran) tidak dilakukan karena keterbatasan waktu penelitian.

Tahapan penelitian ini meliputi pendefinisian masalah melalui analisis 
kebutuhan di lapangan (tahap define). Setelah memperoleh informasi dari analisis kebutuhan, kemudian dilakukan perancangan desain awal yaitu modul SETS (Science, Environment, technology, and society) pada materi cahaya dan alat optik kelas VIII SMP/MTs (tahap design). Selanjutnya, draf modul divalidasi oleh ahli materi, ahli media, praktisi pendidikan, dan peer review serta diujicobakan secara terbatas pada 10 peserta didik SMP Negeri 1 Banyudono. Validasi modul ditujukan untuk melihat layak atau tidaknya modul hasil pengembangan.

Subyek uji coba pengembangan ini meliputi: (1) Dosen ahli materi, (2) Dosen ahli media, (3) Praktisi pendidikan (Guru IPA), (4) Peer review, (5) Uji coba terbatas meiputi 10 peserta didik SMP Negeri 1 Banyudono.

Sumber data berasal merupakan data primer yang diperoleh dari evaluasi terhadap kelayakan produk yang dikembangkan. Jenis data yang diperoleh yaitu data kuantitatif dan kualitatif.

Data hasil validasi dari para ahli dan data uji coba terbatas kemudian dihitung bobot skor dari masing-masing aspek berdasarkan rumus perhitungan validasi yang mengacu pada Akbar (2013) berikut:

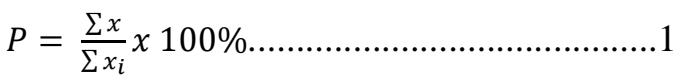

Keterangan:

$\mathrm{P} \quad=$ presentase yang dicari

$\Sigma x=$ total skor setiap aspek

$\Sigma x_{\mathrm{i}} \quad=$ total skor maksimal

Selanjutnya, perolehan presentase skor dirujuk pada kriteria tingkat kevalidan modul menurut Akbar (2013) seperti pada Tabel 1. berikut:

Tabel 1. Kriteria Validitas

\begin{tabular}{lll}
\hline \multicolumn{1}{c}{ Skor } & \multicolumn{1}{c}{ Kriteria } \\
\hline $85,01-100$ & $:$ & $\begin{array}{l}\text { Sangat valid/sangat layak, dapat } \\
\text { digunakan tetapi perlu revisi kecil }\end{array}$ \\
\hline $70,01-85,00$ & $:$ & $\begin{array}{l}\text { Valid/layak, dapat digunakan tetapi } \\
\text { perlu revisi kecil }\end{array}$ \\
\hline $50,01-70,00$ & $:$ & $\begin{array}{l}\text { Kurang valid/kurang layak, dapat } \\
\text { digunakan tetapi perlu revisi besar }\end{array}$ \\
\hline $01,00-50,00$ & $:$ & $\begin{array}{l}\text { Tidak valid/tidak layak, tidak boleh } \\
\text { dipergunakan }\end{array}$ \\
\hline
\end{tabular}

\section{Hasil Penelitian dan Pembahasan}

Hasil penelitian pengembangan ini yaitu berupa modul SETS (Science, Environment, Technology, and Society) pada Materi Cahaya dan Alat Optik Kelas VIII SMP/MTs. Penelitian pengembangan modul ini menggunakan model pengembangan 4-D yang meliputi tahap define, design, develop, dan disseminate. Pada penelitian hanya dilakukan sampai uji coba terbatas pada tahap develop (3-D) saja. Berikut uraian tahapan pengembangan penelitian secara lengkap.

\section{Define (Pendefinisian)}

Tahap ini adalah tahap identifikasi masalah yang ada di lapangan yang kemudian dijadikan dasar serta acuan untuk membuat rancangan dasar modul yang akan dikembangkan. Menurut Sari et al. (2016), tahapan ini terdiri dari lima langkah, yaitu front-end analysis, student analysis, task analysis, concept analysis dan specifying instructional objectives.

Hasil wawancara pada Guru IPA dan observasi di SMP Negeri 1 Banyudono diperoleh bahwa pendekatan yang biasa digunakan adalah pendekatan saintifik dengan model discovery learning. Sedangkan metode yang digunakan oleh guru metode ceramah, eksperimen, tanya-jawab, dan penugasan. Penggunaan model serta metode yang kurang bervariasi menyebabkan hasil belajar peserta didik rendah (Asmuri, et al., 2018).

Bahan ajar yang digunakan masih terbatas dari buku sekolah elektronik dari Kemendikbud dan sebuah buku pendamping dari penerbit. Guru mengatakan bahwa cakupan materi yang ada di kedua buku tersebut masih kurang dan belum memenuhi kebutuhan peserta didik apabila ingin belajar mandiri. Bahan ajar yang tidak memiliki cakupan materi luas kurang menunjang kebutuhan peserta didik. Hal tersebut sesuai dengan yang disampaikan Setianingsih, et al. (2018) yang mengatakan jika rendahnya motivasi peserta didik dalam belajar akibat bahan ajar yang hanya memuat sedikit ringkasan materi.

Berdasarkan hasil wawancara, peserta didik memiliki kesulitan dalam materi IPA yang terdapat hitungan serta cenderung lebih antusias saat menggunakan metode eksperimen. Namun metode eksperimen jarang 
diterapkan akibat keterbatasan waktu dan juga ruang karena proses pembangunan membuat laboratorium dialihfungsikan sebagai ruang kelas. Sehingga diperlukan sebuah bahan ajar yang dapat mendorong peserta didik untuk melakukan eksperimen secara mandiri dan bahan ajar yang memuat cakupan materi yang lebih mendalam.

Analisis tugas dan konsep dilakukan dengan menganalisis kurikulum yang ada di sekolah. Kemudian dipilih Kompetensi Dasar yang akan dikembangkan berdasarkan analisis permasalahan yang ada, lalu dikembangkan menjadi indikator-indikator. Setelah itu tujuan pembelajaran ditetapkan berdasarkan indikator yang telah dikembangkan (Sari et al., 2016).

\section{Design (Perancangan)}

Tahap design (perancangan) merupaka tahap perancangan desain modul awal. Tahapan ini dibagi menjadi 4 tahap, yaitu constructing instrument, media selection, format selection, dan initial design. Penyusunan instrumen (constructing instrument) dilakukan untuk menyusun angket validasi yang kemudian digunakan beberapa ahli dalam menilai modul hasil pengembangan dan digunakan untuk melihat respon peserta didik. Angket validasi serta angket respon peserta didik disusun berdasarkan skala likert dengan empat tingkatan, yaitu baik/ setuju (4), cukup baik/ cukup setuju (3), kurang baik/ kurang setuju (2), dan tidak baik/ tidak setuju (1).

Pemilihan media berupa modul yang dapat membantu peserta didik dalam melakukan pembelajaran mandiri. Modul disusun mengacu pada format kepenulisan modul oleh Departemen Pendidikan Nasional (2008) yang disesuaikan dengan langkahlangkah pendekatan SETS menurut Pedretti dan Nazir (2011). Perancangan desain awal menghasilkan desain awal modul yang terbagi menjadi tiga bagian, yaitu bagian bagian awal, inti, dan akhir. Bagian awal berisi sampul (cover), kata pengantar, panduan penggunaan modul, daftar isi, peta konsep, dan pengantar. Bagian inti terdiri dari enam kegiatan pembelajaran yang disesuaikan dengan pendekatan SETS, yaitu "Ayo Amati dan Diskusi!”, “Ayo Lakukan!", “Ayo Pahami Kembali!", "Ayo Belajar Teknologi!”, "Ayo Hubungkan!", dan "Ayo Ingat Kembali!".
Bagian akhir berisi rangkuman, evaluasi, kunci jawaban, daftar pustaka, dan glosarium.

\section{Develope (Pengembangan)}

Tahap ini dibagi menjadi tiga tahap, yaitu tahapan validasi ahli, uji coba terbatas, dan revisi produk. Tahapan validasi merupakan tahap penilaian modul oleh dua ahli materi serta dua ahli media yang merupakan dosen dari Pendidikan Fisika UNS dan Pendidikan IPA UNY, dua praktisi pendidikan yang merupakan Guru IPA di SMP Negeri 1 Banyudono, serta dua peer review yang merupakan rekan sejawat dari S1 Program Studi Pendidikan IPA UNS. Hasil validasi oleh ahli materi dan ahli media tersaji pada Tabel 2.

Tabel 2. Hasil Validasi Ahli Materi \& Ahli Media

\begin{tabular}{lrrrr}
\hline Validator & & $\begin{array}{c}\text { Presentase } \\
\text { Skor }(\%)\end{array}$ & $\begin{array}{c}\text { Rata- } \\
\text { rata } \\
(\%)\end{array}$ & Kriteria \\
\hline $\begin{array}{lllll}\text { Ahli } \\
\text { Materi }\end{array}$ & I & 84,48 & 88,00 & Sangat Layak \\
\cline { 2 - 3 } Ahli & II & 91,52 & & \\
Media & I & 92,30 & & \\
\cline { 2 - 3 } & II & 95,47 & 93,88 & Sangat Layak \\
\hline \multicolumn{4}{l}{ Rata-rata keseluruhan } \\
\hline
\end{tabular}

Berdasarkan Tabel 2., penilaian diperoleh dari dua ahli materi dan dua ahli media. Hasil validasi ahli materi menyatakan bahwa modul memperoleh kriteria sangat layak dari segi materi dengan presentase ratarata $88,00 \%$. Validasi materi dilakukan untuk melihat layak atau tidaknya materi hasil pengembangan yang disajikan dalam modul berdasarkan aspek kelayakan isi, kebahasaan, penyajian (BSNP, 2008) dan pendekatan SETS (Pedretti \& Nazir, 2011). Menurut Setianingsih (2018), validasi ahli materi diperlukan untuk mengetahui kebenaran isi dari modul yang dikembangkan. Secara keseluruhan, ahli materi menilai bahwa cakupan dan kedalaman materi pada modul telah sesuai dengan tingkat perkembangan intelektual emosional siswa SMP. Hal tersebut sesuai dengan penelitian yang dilakukan oleh Sari, et al. (2016), Rochmawati, et al. (2017), dan Tamimiya, et al. (2017) yang menghasilkan modul SETS dengan kriteria 
layak digunakan berdasarkan hasil validasi materi.

Selanjutnya, validasi media yang ditujukan untuk melihat kelayakan modul ditinjau dari aspek kegrafikaan, yang terdiri dari indikator ukuran modul, desain sampul modul, serta desain isi modul. Hal ini juga disampaikan oleh Asmuri et al. (2018) bahwa validasi media diperlukan untuk melihat kelayakan format modul hasil pengembangan. Hasil dari validasi media didapatkan presentase 93,88\% dengan kriterianya "Sangat Layak". Hasil tersebut sesuai dengan penelitian Asmuri et al. (2018) yang menghasilkan modul SETS dengan kriteria baik sehingga layak digunakan berdasarkan validasi ahli media.

Kemudian validasi juga dilakukan oleh praktisi pendidikan (Guru IPA) dan juga peer review (teman sejawat). Hasil validasi tersaji pada Tabel 3. berikut.

Tabel 3. Hasil Validasi Guru IPA \& Peer Review

\begin{tabular}{|c|c|c|c|c|}
\hline Validato & & $\begin{array}{c}\text { Presentase Skor } \\
(\%)\end{array}$ & $\begin{array}{c}\text { Rata- } \\
\text { rata }(\%)\end{array}$ & Kriteria \\
\hline \multirow{2}{*}{$\begin{array}{l}\text { Guru } \\
\text { IPA }\end{array}$} & I & 96,36 & \multirow{2}{*}{96,31} & \multirow{2}{*}{ Sangat Layak } \\
\hline & II & 96,26 & & \\
\hline \multirow{2}{*}{$\begin{array}{l}\text { Peer } \\
\text { Review }\end{array}$} & I & 97,82 & \multirow{2}{*}{95,98} & \multirow{2}{*}{ Sangat Layak } \\
\hline & II & 94,13 & & \\
\hline \multicolumn{3}{|c|}{ Rata-rata keseluruhan } & 96,12 & Sangat Layak \\
\hline
\end{tabular}

Berdasarkan Tabel 2., penilaian diperoleh dari dua guru IPA SMP Negeri 1 Banyudono dan dua peer review yang merupakan teman sejawat di program studi S1 Pendidikan IPA Universitas Sebelas Maret. Validasi oleh Guru IPA serta validasi oleh peer review dilakukan untuk mengetahui kelayakan isi dan keterbacaan modul (Setianingsih et al., 2018). Validasi oleh Guru IPA memperoleh rata-rata presentase $96,31 \%$ sehingga masuk dalam kriteria "Sangat Layak". Validasi oleh peer review diperoleh kriteria modul sangat valid dengan presentase hasil validasi sebesar 95,98\%

Berdasarkan validasi ahli, modul memperoleh penilaian dengan presentase ratarata sebesar 93,54\% dan dapat dikategorikan sangat layak berdasarkan kriteria validitas ahli menurut Akbar (2013). Sehingga dapat ditarik kesimpulan bahwa modul hasil pengembangan layak digunakan berdasarkan validasi ahli. Hasil ini sejalan dengan penelitian Sari, et al.
(2016), Rochmawati, et al. (2017), Tamimiya, et al. (2017), dan Asmuri et al. (2018) yang menghasilkan modul SETS dengan kriteria layak ditinjau dari hasil validasi para ahli.

Hasil penilaian tersebut disertai dengan saran perbaikan yang dapat dijadikan acuan revisi produk hasil pengembangan. Adapun beberapa saran perbaikan dari para ahli 1) Perbaiki beberapa tata kepenulisan; 2) Lengkapi beberapa gambar dan info pada bagian teks; 3) Tambahkan deskripsi tentang unsur-unsur SETS dalam tabel di setiap awal topik; 5) Aspek lingkungan belum tampak, akan lebih baik apabila ditambahkan sub judul terkait integrasi keempat unsur SETS; 6) Pilih gambar yang proporsional dan menggambarkan konektivitas antara sains, lingkungan, teknologi, dan masyarakat; 7) Pilih warna latar belakang pada tulisan agar tidak terlalu kontras; 8) Perbaiki beberapa format kepenulisan seperti margin, footer, dan justify; 9) Tambahkan latihan-latihan soal; 10) Tambahkan barcode pada laman web yang tersedia. Beberapa saran perbaikan tersebut digunakan untuk melakukan revisi terhadap modul.

Setelah validasi ahli, uji coba terbatas dilakukan terhadap 10 peserta didik kelas IXD SMP Negeri 1 Banyudono. Uji coba terbatas ditujukan untuk melihat keterbacaan modul serta respon peserta didik terhadap modul yang dikembangkan (Setianingsih et al., 2018). Hasil dari uji coba terbatas tersaji pada Tabel 4. berikut.

Tabel 4. Hasil Uji Coba Terbatas

\begin{tabular}{lcc}
\hline Aspek Penilaian & $\begin{array}{c}\text { Presentase } \\
\text { Rata-Rata (\%) }\end{array}$ & Kriteria \\
\hline Tampilan & 92,00 & Sangat Layak \\
Penyajian Materi & 86,07 & Sangat Layak \\
Bahasa & 93,13 & Sangat Layak \\
Manfaat & 83,13 & Layak \\
\hline Rata-rata & 88,58 & Sangat Layak \\
\hline
\end{tabular}

Tabel 4. menunjukkan rata-rata perolehan skor setiap aspek dalam tahap uji coba terbatas. Rata-rata keseluruhan aspek pada uji coba terbatas diperoleh presentase $88,58 \%$ dan dapat dikategorikan "Sangat Layak". Hasil dari uji coba terbatas pada modul ini sejalan dengan penelitian Tamimiya, et al. (2017) yang memperoleh hasil dengan 
kriteria sangat valid serta layak digunakan pada pembelajaran.

\section{Kesimpulan dan Rekomendasi}

Berdasarkan data hasil penelitian dan pembahasan dapat disimpulkan bahwa modul SETS pada materi cahaya dan alat optik yang dikembangkan sangat layak digunakan untuk aspek keterbacaan materi dan sangat layak untuk aspek kegrafikaan berdasarkan validasi ahli. Menunjukkan kriteria sangat layak untuk aspek kebahasaan, penyajian materi, tampilan, dan manfaat berdasarkan validasi praktisi pendidikan dan peer review. Menunjukkan kategori sangat layak untuk aspek keterbacaan modul berdasarkan uji coba terbatas pada 10 peserta didik SMP Negeri 1 Banyudono.

\section{Daftar Pustaka}

Akbar, S. (2013). Instrumen Perangkat Pembelajaran, PT Remaja Rosdakarya, Bandung.

Asmuri, Sarwanto, \& Masykuri, M. (2018). Pengembangan Modul IPA Terpadu SMP / MTs Kelas VIII Berbasis SETS untuk Meningkatkan Kemampuan Berpikir Kritis Siswa pada Tema Makanan dan Kesehatan Tubuh. Seminar Nasional Pendidikan Fisika, September 2018, hal. 73-80.

Bencze et al. (2019). SAQ, SSI and STSE education: defending and extending "science-in context". Cultural Studies of Science Education, 1 (1):1-28.

BSNP. (2007). Kapal Itu Bernama UN. Buletin BSNP, BSNP, Jakarta.

Chowdhury, M. A. (2016). The Integration of Science-Technology-Society/Science-

Technology-Society-Environment an,,dd Socio-Scientific-Issues for Effective Science Education and Science Teaching. Electronic Journal of Science Education, 20 (5):19-38.

Depdiknas. (2008). Penulisan Modul, Departemen Pendidikan Nasional, Jakarta.

Harahap, Y. N., Indriyanti, D. R., \& Marianti, A. (2017). Pembelajaran Biologi Materi Sistem Pertahanan Tubuh dengan Pendekatan SETS pada Siswa SMA. Journal of Biology Education, 6 (1):95-103.

Hayati, I. A., Rosana, D., \& Sukardiyono. (2019). Pengembangan Modul Potensi Lokal Berbasis SETS Untuk Meningkatkan Keterampila Proses IPA. Jurnal Inovasi
Pendidikan IPA, 5 (2), hlm. 248-257. Diperoleh 19 Desember 2020, dari https://doi.org/ 10.21831/jipi.v5i2.27519

OECD. (2018). PISA 2018: Insights and Interpretations, OECD Publishing, Paris.

Rahim, F. R. (2019). Pendekatan SETS, PACE, Multiple Intelligence, Metacognitive Skill, dan $R M E$ dalam Pembelajaran IPA Terpadu. Jurnal Semesta Pendidikan, 2 (1): 26-31.

Pedretti, E., \& Nazir, J. (2011). Currents in STSE education: Mapping a complex field, 40 years on. Science Education, 95: 601-626. https://doi.org/10.1002/sce.20435

Sari, D. Y. K, Wahyuni, S., \& Supriadi, B. (2016). Pengembangan Modul Pembelajaran IPA Berbasis Salingtemas (Sains, Lingkungan, Teknologi, Masyarakat) di SMP. Jurnal Pembelajaran Fisika, 5 (3):218 - 225.

Setianingsih, E., Sunarno, W., \& Sukarmin. (2018). Pengembangan Modul Pembelajaran Dinamika Gerak Berbasis Inkuiri Terbimbing untuk Siswa Kelas X SMA/MA. Jurnal Pendidikan IPA, 7 (2): 220-231. https://doi.org/10.20961/inkuiri.v7i2.22978

Rochmawati, Y., Wahyuni, S., \& Bachtiar, R. W. (2017). Peran Pendidikan, Sains, dan Teknologi untuk Mengembangkan Budaya Ilmiah dan Inovasi terbarukan dalam mendukung Sustainable Development Goals (SDGs) 2030. Seminar Nasional Pendidikan Fisika 2017, hlm. 1-6.

Safitri, A. N., Subiki, \& Wahyuni, S. (2018). Pengembangan Modul IPA Berbasis Kearifan Lokal Kopi pada Pokok Bahasan Usaha dan Energi di SMP. Jurnal Pembelajaran Fisika, 7 (1), hlm. 22-29. Diperoleh 31 Mei 2020, dari https://jurnal.unej.ac.id/index.php/JPF/articl e/download/7221/5221

Wijaya, I. K. W. B. \& Fajar, A. M. (2020). Pengembangan Modul Pembelajaran Berorientasikan Problem Based Learning (PBL) Untuk Meningkatkan Keterampilan Proses Sains Siswa pada Materi Cahaya dan Alat Optik. Jurnal Inovasi Pendidikan Sains, 11 (1), hlm. 8-17. Diperoleh 31 Mei 2020, dari https://www.researchgate.net/publication/32 2996178

Yuliati, N. (2015). Peningkatan Motivasi Belajar IPA Melalui Metode Demonstrasi di SMP Negeri 10 Probolinggo. Jurnal Kebijakan dan Pengembangan Pendidikan, 3 (1):3541. 